\title{
The association of fish consumption with bladder cancer risk: A meta-analysis
}

\author{
Zhongyi Li', Jianda Yu, Qilong Miao, Shuben Sun, Lingjun Sun, Houmen Yang and Liejun Hou
}

\begin{abstract}
Background: The association between fish consumption and risk of bladder cancer has not been established yet. The results from epidemiological studies are inconsistent.

Methods: We conducted a meta-analysis of cohort and case-control studies on the relationship between fish intake and bladder cancer. We quantified associations with bladder cancer using meta-analysis of relative risk associated to the highest versus the lowest category of fish intake using random effect models. Heterogeneity among studies was examined using $Q$ and $I^{2}$ statistics. Publication bias was assessed using the Begg's funnel plot.

Results: Five cohort and 9 case-control studies were eligible for inclusion. The combined relative risk showed that fish consumption was negatively, but not significantly, associated with a decreased risk of bladder cancer (relative risk, 0.86; 95\% confidence interval, 0.61-1.12). In subgroup analyses, there was no evidence that study design, geographical region, case sample size, or exposure assessment substantially influenced the estimate of effects.

Conclusion: The overall current literature on fish consumption and the risk of bladder cancer suggested no association. Because of the limited number of studies, further well-designed prospective studies are needed to explore the effect of fish on bladder cancer.
\end{abstract}

Keywords: Bladder neoplasms, Diet, Fish, Meta-analysis, Prevention

\section{Background}

Bladder cancer is the second most common urologic malignancy and the seventh most common cancer in men. It has been estimated that 386,300 patients are newly diagnosed with bladder cancer worldwide in 2008 , and approximately 150,200 patients were expected to die of it [1]. Depending on its stage and grade, bladder cancer may be treated with surgery, radiation therapy, chemotherapy, or immunotherapy. Because bladder cancer has the highest lifetime treatment cost of any cancer, and direct exposure to carcinogens is implicated in bladder cancer development and many potentially protective compounds are concentrated in urine, making it an ideal target for preventive therapies [2].

Smoking, occupational exposure, and chronic infections with schistosoma are the most established risk factors for bladder cancer. At present, evidence on dietary factors is also accumulating. Fish plays an important role in the usual diet worldwide and is an ideal source of n-3 polyunsaturated fatty acids, which may lower cancer risk by suppressing mutations, inhibiting cellular proliferation, and inducing cell apoptosis [3-5]. A report by the World Cancer Research Fund and the American Institute for Cancer Research on the relationship between diet and cancer concluded, based on a comprehensive review of epidemiologic studies, that fish consumption may possibly protect against cancers of the colon, rectum, and ovary [6]. Less attention, however, has been paid to the role of fish consumption on bladder cancer risk. Several epidemiological studies have examined the association between fish intake and the risk of bladder cancer; the majority of results are null, which could possibly be attributable to lack of statistical power in individual studies. Thus, we conducted a meta-analysis of all published studies to evaluate the relationship between fish consumption and bladder cancer.

\footnotetext{
* Correspondence: mymqq@yahoo.com.cn

Department of Urology, the Affiliated Hospital of School of Medicine of Ningbo University, Ningbo, Zhejiang, 315020, China
}

(c) $2011 \mathrm{Li}$ et al; licensee BioMed Central Ltd. This is an Open Access article distributed under the terms of the Creative Commons Attribution License (http://creativecommons.org/licenses/by/2.0), which permits unrestricted use, distribution, and reproduction in any medium, provided the original work is properly cited. 


\section{Methods and materials}

\subsection{Search strategy}

We identified studies by a literature search of the PubMed databases up to January 2011 with the following key words: "fish," "meat," or "diet" combined with "bladder cancer," "urothelial cancer," or "urinary tract cancer." In addition, we reviewed the reference lists from all relevant articles to identify additional studies. All searches were conducted independently by two authors. The results were compared, and any questions or discrepancies were resolved through iteration and consensus.

\subsection{Study selection}

Following criteria were used to identify relevant studies for the meta-analysis. First, they had to be case-control or cohort studies in English language. Second, the studies needed to examine fish consumption as a risk factor for bladder cancer. Last, each study should provide risk estimate together with its corresponding $95 \%$ confidence interval (CI) adjusted for at least age, sex and smoking (or sufficient information to calculate it). We also included the articles evaluating the risk of urinary tract cancer with fish consumption, for bladder cancer accounts for the overwhelming majority of tumors, and the renal pelvis and ureter are covered by the same urothelium. The term bladder cancer was used as a synonym for these neoplasms.

The process of study selection was shown in Figure 1. Seventeen potentially relevant studies were identified by searching PubMed and references of retrieved articles or reviews [3,7-22]. Three studies were excluded because one reported only odds ratio (OR) but no $95 \% \mathrm{CI}$ [8], and two presented the ORs for meat and fish consumption together $[11,13]$. Thus, a total of 14 studies were included in this meta-analysis.

\subsection{Data extraction}

The following data were extracted independently by two authors from each study: the name of the first author, year of publication, the country in which the study was conducted, study design, study period, sample size, exposure of fish consumption, risk estimates with corresponding 95\% CIs for highest vs lowest level of fish consumption, covariates controlled for in the analysis and exposure assessment. Because bladder cancer is a rare disease, OR can be interpreted as RR. For simplicity, we report all results as $R R$.

\subsection{Statistical analysis}

We estimated a pooled RR with $95 \%$ CI based on random-effects models, which incorporates both within and between-study variability [23]. One study reported sexstratified RRs, we calculated the overall sex-adjusted RR by combining the two estimates with the method of
Mantel and Haenszel [24]. Heterogeneity was assessed using Q-test [23] and $\mathrm{I}^{2}$ score [25], and statistical significance was considered while $\mathrm{P}<0.05$. A sensitivity analysis was conducted to test the impact of each study on the pooled estimates by removing each study from the meta-analysis separately. Publication bias was assessed through visual inspection of funnel plots, and tests of Begg [26]. We performed meta-regression analysis to explore the influence of study design, geographical region and publication years in the heterogeneity. All statistical analyses were conducted using Stata (StataCorp, College Station, Texas).

\section{Results}

Table 1 presents the basic characteristics of each study included in our meta-analysis. There were 5 cohorts and 9 case-control studies (3 population-based and 6 hospital-based case-control studies). Seven studies were conducted in Europe, 3 in US/Canada, 3 in Japan, and the remaining one in Uruguay. Most studies have reported non-significant associations, and the risks were significantly decreased in 2 studies.

Risk estimates for highest $v s$ lowest level of fish consumption are shown in Figure 2. The summary RR of all studies, using a random effects model, did not show that fish consumption was significantly associated with decreased risk of bladder cancer (RR, 0.86; 95\% CI, 0.611.12). There was statistically significant heterogeneity across the studies $\left(\mathrm{P}<0.001, \mathrm{I}^{2}=85.4 \%\right)$. Begg's funnel plot indicated that there was no significant publication bias (Figure $3, \mathrm{P}=0.101$ ). A sensitivity analysis in which one study at a time removed was performed to evaluate the stability of the results. The summary RR ranged from 0.83 (95\% CI, 0.57-1.10) (when excluding the study by Riboli et al [10]) to 0.91 (95\% CI, 0.63-1.20) (when excluding the study by sakauchi et al [17]), indicating the stability of results.

To explore the source of heterogeneity, we next pooled the RR estimates by study design, geographical region, and exposure assessment (Table 2). The summary RRs neither from cohort studies (RR, 0.84; 95\% CI, 0.42-1.26) nor from all case-control studies (RR, 0.87; 95\% CI, 0.541.21) showed that fish intake was related to decreased bladder cancer risk. When we separated the populationbased case-control studies from their hospital-based case-control studies, we found no apparent difference between hospital-based case-control studies (RR, 0.88; 95\% CI, 0.40-1.36) and population-based case-control studies (RR, 0.83; 95\% CI, 0.63-1.03). In addition, the RR estimates showed fish consumption was consistently associated with a decreased but non-significant risk of bladder cancer when separately analyzed by geographical region and exposure assessment. We also performed subgroup analysis by case sample size. The studies which 


\section{Total of article identified by primary search in Pubmed

$$
(n=615)
$$

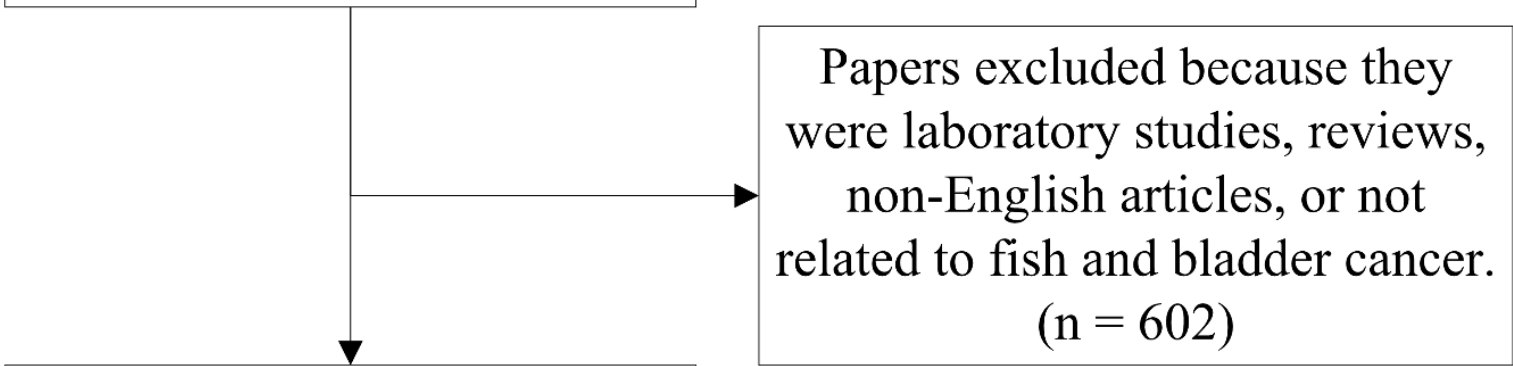

Potentially appropriate articles

$$
(n=13)
$$

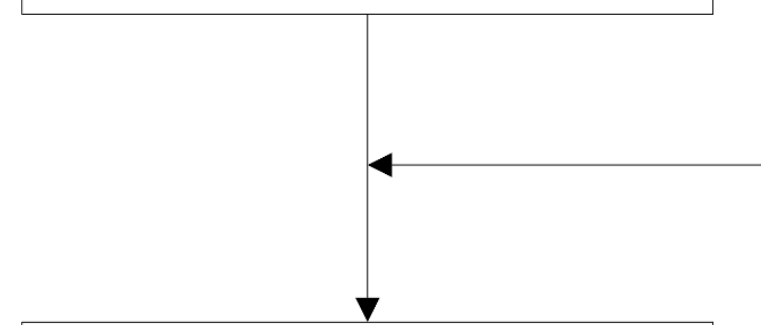

Additional papers identified from reference lists of reviews and retrieved articles.

$$
(n=4)
$$

\section{Studies for detailed evaluation}

$$
(\mathrm{n}=17)
$$

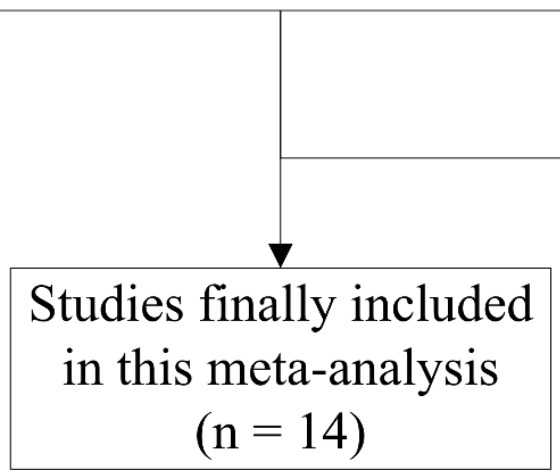

\section{Papers excluded because they did not provided risk ratios or $95 \%$ CIs.

$$
(n=3)
$$

Figure 1 Process of study selection for fish consumption and risk of bladder cancer.

included more than 200 cases of bladder cancer were defined as "large", and those with less than 200 cases were considered as "small". We found a marginally decreased risk of bladder cancer for studies of small case sample size (RR, 0.68; 95\% CI, 0.34-1.02). However, the combined RR for studies with larger case sample size, which provide more reliable results, supported that fish intake was not related to risk of bladder cancer.

Meta-regression analysis was used to explore the influence of publication year, geographical region, study design, case sample size and exposure assessment in the heterogeneity. However, none of them was identified as a possible source of heterogeneity among all the included studies.

\section{Discussion}

Diet is considered to play a very important role in preventing cancer. Fish is an important aspect of diet that has been linked favorably or unfavorably to the risk of several cancers. On the one hand, there are serious 
Table 1 Study characteristics of published cohort and case-control studies on fish intake and bladder cancer

\begin{tabular}{|c|c|c|c|c|c|c|c|c|}
\hline $\begin{array}{l}\text { Authors and } \\
\text { publication } \\
\text { year }\end{array}$ & $\begin{array}{l}\text { Study } \\
\text { design }\end{array}$ & Country & $\begin{array}{l}\text { Study } \\
\text { period }\end{array}$ & $\begin{array}{l}\text { Cases/ } \\
\text { subjects }\end{array}$ & Fish consumption & $\begin{array}{l}\mathrm{RR}(95 \% \\
\mathrm{Cl})\end{array}$ & Variables of adjustment & Assessment \\
\hline $\begin{array}{l}\text { Steineck et al. } \\
1988\end{array}$ & Cohort & Sweden & 1968-1982 & $\begin{array}{l}80 / \\
16477\end{array}$ & Ever vs ever & $1.3(0.8-2.2)$ & Age, sex and smoking & Questionnaire \\
\hline $\begin{array}{l}\text { Steineck et al. } \\
1990\end{array}$ & PCC & Sweden & 1985-1987 & $326 / 719$ & $\begin{array}{l}\text { Weekly vs more } \\
\text { seldom }\end{array}$ & $1.1(0.7-1.8)$ & Age, sex and smoking & Questionnaire \\
\hline $\begin{array}{l}\text { Riboli et al. } \\
1991\end{array}$ & $\mathrm{HCC}$ & Spain & 1985-1986 & $\begin{array}{l}432 / \\
1221\end{array}$ & $\begin{array}{l}\text { The highest vs the } \\
\text { first quartile }\end{array}$ & $\begin{array}{l}1.26(0.86- \\
1.84)\end{array}$ & Age, smoking and total calories & Interview \\
\hline $\begin{array}{l}\text { Chyou et al. } \\
1993\end{array}$ & Cohort & USA & 1965-1991 & $96 / 7090$ & $\begin{array}{l}\geq 5 \text { times/wk vs } \leq \\
\text { once/wk }\end{array}$ & $\begin{array}{l}0.67(0.26- \\
1.67)\end{array}$ & Age, smoking & $\begin{array}{l}\text { Both } \\
\text { techniques }\end{array}$ \\
\hline $\begin{array}{l}\text { Fernandez et al. } \\
1999\end{array}$ & $\mathrm{HCC}$ & Italy & 1983-1996 & $\begin{array}{l}431 / \\
7990\end{array}$ & $\begin{array}{l}\geq 2 \text { servings/wk vs } \\
<1 \text { serving/wk }\end{array}$ & $1.4(1.0-1.8)$ & $\begin{array}{l}\text { Age, sex, area of residence, education, smoking, alcohol consumption, and body } \\
\text { mass index }\end{array}$ & Interview \\
\hline $\begin{array}{l}\text { Nagano et al. } \\
2000\end{array}$ & Cohort & Japan & 1979-1993 & $\begin{array}{l}114 / \\
38540\end{array}$ & $\begin{array}{l}\geq 5 \text { times/wk vs } \leq \\
\text { once/wk }\end{array}$ & $\begin{array}{l}1.31(0.75- \\
2.25)\end{array}$ & $\begin{array}{l}\text { Age, gender, radiation dose, smoking status, education level, body mass index and } \\
\text { calendar time }\end{array}$ & Questionnaire \\
\hline $\begin{array}{l}\text { Wakai et al. } \\
2000\end{array}$ & $\mathrm{HCC}$ & Japan & 1996-1999 & 297/592 & $\begin{array}{l}\text { The highest vs the } \\
\text { first quartile }\end{array}$ & $\begin{array}{l}0.86(0.54- \\
1.38)\end{array}$ & Age, sex, smoking and occupational history as a cook. & Interview \\
\hline $\begin{array}{l}\text { Balbi et al } \\
2001\end{array}$ & $\mathrm{HCC}$ & Uruguay & 1998-1999 & $144 / 720$ & $\begin{array}{l}\text { The highest vs the } \\
\text { first tertile }\end{array}$ & $\begin{array}{l}0.82(0.49- \\
1.36)\end{array}$ & $\begin{array}{l}\text { Age, sex, residence, urban/rural status, education, body mass index, tobacco } \\
\text { smoking, 'mate' drinking, and total calories. }\end{array}$ & Interview \\
\hline $\begin{array}{l}\text { Sakauchi et al. } \\
2005\end{array}$ & Cohort & Japan & 1988-1997 & $\begin{array}{l}115 / \\
65184\end{array}$ & $\begin{array}{l}\text { Almost every day } \\
\text { vs } 1-2 \text { times/month }\end{array}$ & $\begin{array}{l}0.36(0.18- \\
0.72)\end{array}$ & Age, sex and smoking & Questionnaire \\
\hline $\begin{array}{l}\text { Baena et al. } \\
2006\end{array}$ & $\mathrm{HCC}$ & Spain & $\begin{array}{l}\text { Not } \\
\text { mentioned }\end{array}$ & $74 / 163$ & $\begin{array}{l}\geq 3 \text { times/wk vs } \\
\text { never }\end{array}$ & $\begin{array}{l}0.13(0.05- \\
0.33)\end{array}$ & Age, smoking, water intake & Interview \\
\hline $\begin{array}{l}\text { Holick et al. } \\
2006\end{array}$ & Cohort & US & $1986-2002$ & $\begin{array}{l}736 / \\
173229\end{array}$ & $\begin{array}{l}\geq 1 \text { serving/day vs } \\
1-3 \text { serving/month }\end{array}$ & $\begin{array}{l}\text { Men 0.71 } \\
(0.48-1.04) \\
\text { Women } \\
1.33(0.74- \\
2.40)\end{array}$ & Age, sex, total caloric intake, pack-years of cigarette smoking, and current smoking & Questionnaire \\
\hline $\begin{array}{l}\text { Garci'a-Closas et } \\
\text { al. } \\
2007\end{array}$ & $\mathrm{HCC}$ & Spain & 1998-2001 & $\begin{array}{l}873 / \\
1785\end{array}$ & $\begin{array}{l}\text { The highest vs the } \\
\text { first quintile }\end{array}$ & $0.9(0.6-1.2)$ & $\begin{array}{l}\text { Age, gender, region, smoking status, duration of smoking and quintiles of fruit and } \\
\text { vegetable intake }\end{array}$ & Interview \\
\hline $\begin{array}{l}\text { Hu et al. } \\
2008\end{array}$ & PCC & Canada & 1994-1997 & $\begin{array}{l}1029 / \\
6068\end{array}$ & $\begin{array}{l}\text { The highest vs the } \\
\text { first tertile }\end{array}$ & $0.8(0.6-1.1)$ & $\begin{array}{l}\text { Age, province, education, body mass index, sex, alcohol, smoking, total of vegetable } \\
\text { and fruit intake, and total energy intake }\end{array}$ & Questionnaire \\
\hline $\begin{array}{l}\text { Brinkman et al. } \\
2011\end{array}$ & PCC & Belgium & 1999-2004 & $200 / 486$ & $\begin{array}{l}\text { The highest vs the } \\
\text { first tertile }\end{array}$ & $\begin{array}{l}0.77(0.47- \\
1.27)\end{array}$ & $\begin{array}{l}\text { Sex, age, smoking status, number of cigarettes smoked per day, number of years } \\
\text { smoking, occupational exposure to PAHs or aromatic amines and energy intake. }\end{array}$ & Questionnaire \\
\hline
\end{tabular}

PCC: population-base case-control study, HCC: hospital-base case-control study. 


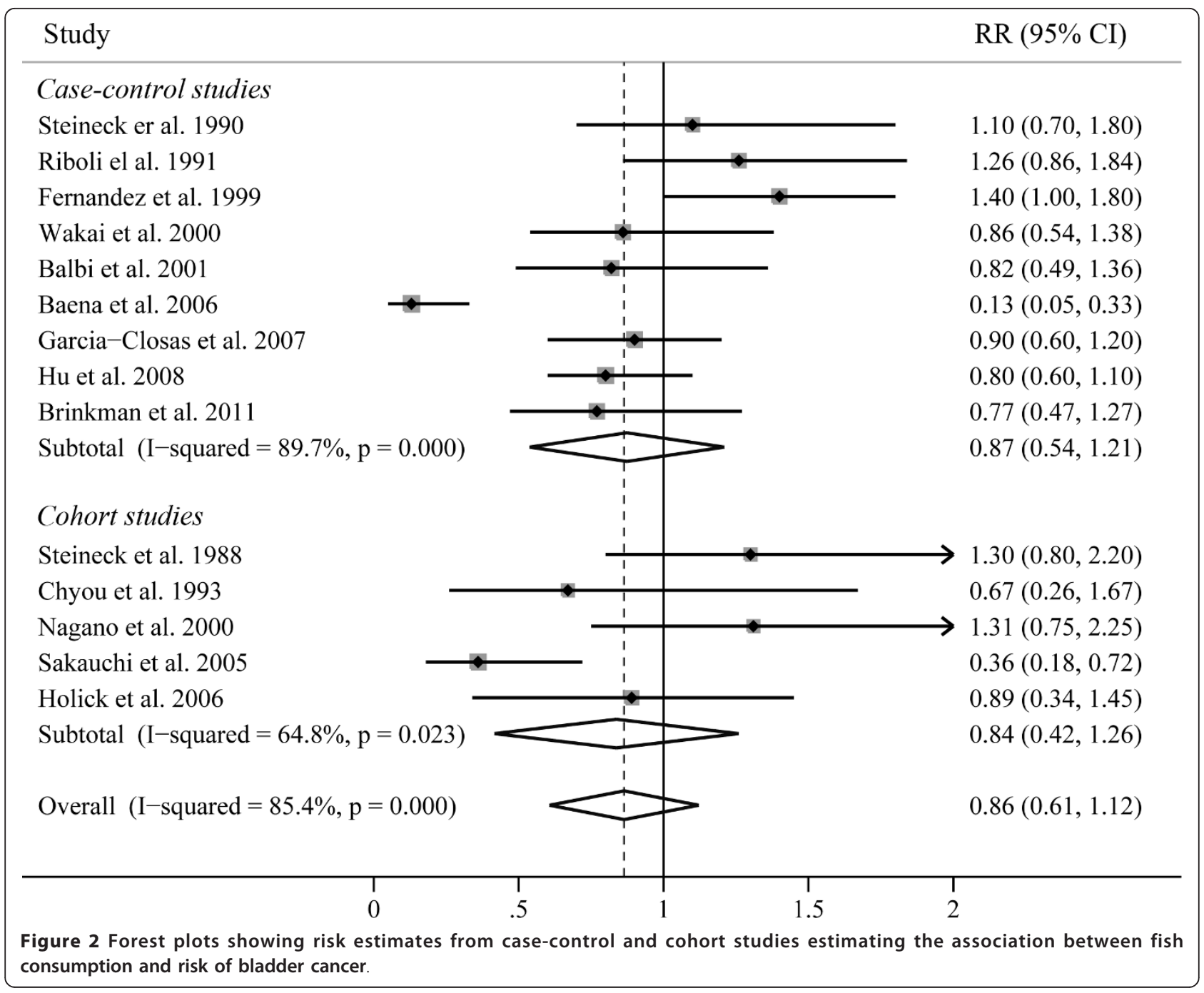

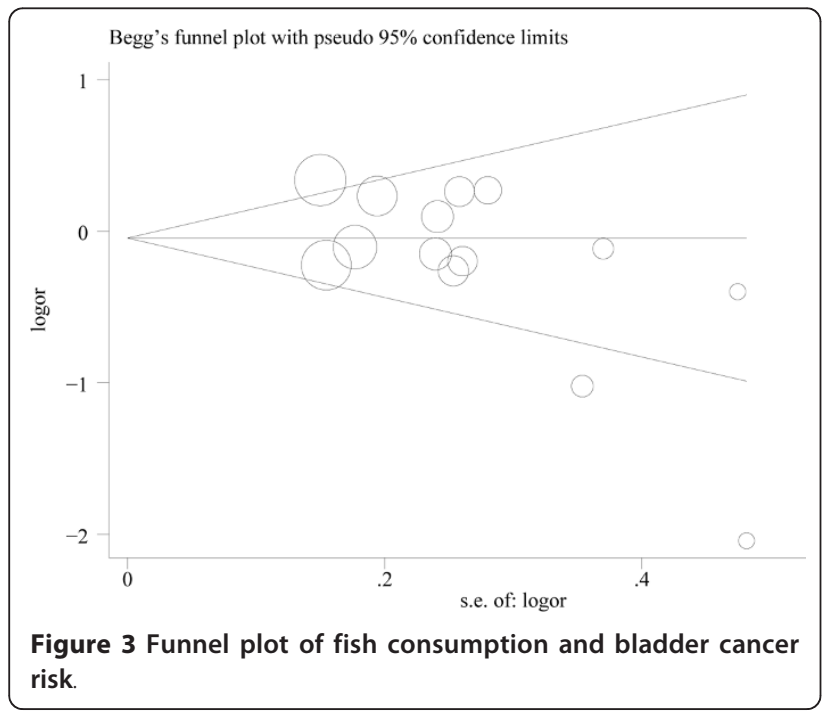

concerns about mercury and other environmental impurities that accumulated in fish. On the other hand, fish is regarded as a terrific source of polyunsaturated fatty acids. This present study is the first meta-analysis summarizing the evidence to date regarding the association between fish consumption and bladder cancer risk. Overall, the summary RR for all of the studies suggested no significant association between fish consumption and the bladder cancer risk. There was a significant heterogeneity among the studies. However, the results were also nonsignificant when the case-control or cohort studies were evaluated individually, or in subgroup analysis by geographical regions, case sample size and exposure assessment. Moreover, we did not identify any potential sources of heterogeneity using meta-regression analysis.

We noted that the associations between fish intake and bladder cancer risk were negative in all studies published after 2000, while the RRs for studies before 2000 tend to be positive (Table 1). This might be explained in part by 
Table 2 Summary of pooled risk ratios of bladder cancer for fish consumer by study design, geographical region, and exposure assessment

\begin{tabular}{|c|c|c|c|c|}
\hline \multirow[t]{2}{*}{ Subgroup } & \multirow[t]{2}{*}{ Number of studies } & \multirow{2}{*}{$\begin{array}{l}\text { Pooled RR } \\
(95 \% \mathrm{Cl})\end{array}$} & \multicolumn{2}{|c|}{ Q-test for heterogeneity } \\
\hline & & & $P$ value & $l^{2}$ score \\
\hline \multicolumn{5}{|l|}{ Study design } \\
\hline Cohort studies & 5 & $0.84(0.42,1.26)$ & 0.023 & $64.8 \%$ \\
\hline Case-control studies & 9 & $0.87(0.54,1.21)$ & $<0.001$ & $89.7 \%$ \\
\hline Hospital-based case-control studies & 6 & $0.88(0.40,1.36)$ & $<0.001$ & $92.5 \%$ \\
\hline Population-based case-control studies & 3 & $0.83(0.63,1.03)$ & 0.586 & 0 \\
\hline \multicolumn{5}{|l|}{ Geographical region } \\
\hline Europe & 7 & $0.95(0.49,1.42)$ & $<0.001$ & $91.9 \%$ \\
\hline US/Canada & 3 & $0.80(0.58,1.02)$ & 0.891 & 0 \\
\hline Japan & 3 & $0.76(0.25,1.27)$ & 0.019 & $74.7 \%$ \\
\hline \multicolumn{5}{|l|}{ Exposure assessment } \\
\hline Interview & 6 & $0.88(0.40,1.36)$ & $<0.001$ & $92.5 \%$ \\
\hline Mailed questionnaire & 7 & $0.84(0.58,1.09)$ & 0.025 & $58.5 \%$ \\
\hline \multicolumn{5}{|l|}{ Case sample size } \\
\hline Large & 7 & $0.99(0.82,1.17)$ & 0.215 & $28.0 \%$ \\
\hline Small & 7 & $0.68(0.34,1.02)$ & $<0.001$ & $81.4 \%$ \\
\hline
\end{tabular}

the improvement of the adjustment for smoking in recent years. Cigarette smoking is one of the most important risk factors for bladder cancer, so it is possible that smoking may confound the fish-bladder cancer association if not properly controlled for, which may be particularly true in older studies, leading to spurious positive associations between fish intake and bladder cancer risk. However, we could not provide the separate meta-analyses for nonsmokers and smokers because of the few studies available.

The association between fish intake and bladder cancer is biologically plausible. Fish and fish oil are a rich source of long-chain, n-3 polyunsaturated fatty acids (PUFA), eicosapentaenoic acid (EPA) and docosahexaenoic acid (DHA). The $\mathrm{n}-3$ fatty acids is suggested to reduce cancer risk via several potential mechanisms, including modulation of eicosanoid production and inflammation, angiogenesis, proliferation, susceptibility for apoptosis, and estrogen signaling, which are variables that are key drivers in cancer progression [27]. Using animal models, researchers have found that supplementing the diet of tumor-bearing mice or rats with purified n-3 fatty acids has slowed the growth of various types of cancers [28-30]. In addition, intake of oils containing EPA or DHA has also been shown to suppress cancer growth in animal studies [31-33]. However, no data regarding to the effects of fish ingredients on bladder cancer has been published.

The present study has important limitations which should be considered when interpreting our results. First, fish consumption includes fatty fish, which are much higher in the fatty acids, as well as fish that are lower in marine fatty acids, and many studies have also reported increased cancer risks associated with consumption of salted fish. However, we only assessed total fish consumption because most of these studies were not primarily designed to investigate the effect of fish consumption on bladder cancer risk, and did not specify what type of fish was consumed, providing one explanation for the heterogeneity of the study. Second, only articles published in the English language were included, and we did not search for unpublished studies or original data, although no publication bias was indicated visually or in formal statistical testing. Third, the classification of exposure varied considerably across the included studies, and the different amount of fish consumption may contribute to the heterogeneity among studies in the analysis of the highest versus the lowest intake categories.

\section{Conslusion}

In conclusion, in this meta-analysis of 5 cohorts and 9 case-control studies, we did not found fish consumption was associated with reduced risk of bladder cancer. Given the small number of cohort studies included in this meta-analysis, further prospective cohort studies with larger sample size, well-controlled confounding factors, and more accurate assessment of fish consumption are needed to affirm the effect of fish on bladder cancer.

Authors' contributions

ZL conceived of the study concept and participated in its design, data extraction, statistical analysis, manuscript drafting and editing. JY and QM participated in the literature research, manuscript drafting and editing. SS participated in design and data extraction. LS and HY participated in manuscript drafting, editing and statistical analysis. LH conceived of the 
study concept and participated in data analysis. All authors read and approved the final manuscript.

\section{Competing interests}

The authors declare that they have no competing interests.

Received: 19 June 2011 Accepted: 19 September 2011 Published: 19 September 2011

\section{References}

1. Jemal A, Bray F, Center MM, Ferlay J, Ward E, Forman D: Global cancer statistics. CA Cancer J Clin 2011.

2. Busby JE, Kamat AM: Chemoprevention for bladder cancer. J Urol 2006 176:1914-1920.

3. Fernandez E, Chatenoud L, La Vecchia C, Negri E, Franceschi S: Fish consumption and cancer risk. Am J Clin Nutr 1999, 70:85-90.

4. Karmali RA: n-3 fatty acids and cancer. J Intern Med Supp/ 1989, 731:197-200

5. Rose DP, Connolly JM: Omega-3 fatty acids as cancer chemopreventive agents. Pharmacol Ther 1999, 83:217-244.

6. Glade MJ: Food, nutrition, and the prevention of cancer: a global perspective. American Institute for Cancer Research/World Cancer Research Fund, American Institute for Cancer Research, 1997. Nutrition 1999, 15:523-526.

7. Steineck G, Norell SE, Feychting M: Diet, tobacco and urothelial cancer. A 14-year follow-up of 16,477 subjects. Acta Oncol 1988, 27:323-327.

8. La Vecchia C, Negri E, Decarli A, D'Avanzo B, Liberati C, Franceschi S: Dietary factors in the risk of bladder cancer. Nutr Cancer 1989, 12:93-101.

9. Steineck G, Hagman U, Gerhardsson M, Norell SE: Vitamin A supplements, fried foods, fat and urothelial cancer. A case-referent study in Stockholm in 1985-87. Int J Cancer 1990, 45:1006-1011.

10. Riboli E, Gonzalez CA, Lopez-Abente G, Errezola M, Izarzugaza I, Escolar A, Nebot $M$, Hemon B, Agudo A: Diet and bladder cancer in Spain: a multicentre case-control study. Int J Cancer 1991, 49:214-219.

11. Mills PK, Beeson WL, Phillips RL, Fraser GE: Bladder cancer in a low risk population: results from the Adventist Health Study. Am J Epidemiol 1991, 133:230-239.

12. Chyou PH, Nomura AM, Stemmermann GN: A prospective study of diet, smoking, and lower urinary tract cancer. Ann Epidemiol 1993, 3:211-216.

13. Augustsson K, Skog K, Jagerstad M, Dickman PW, Steineck G: Dietary heterocyclic amines and cancer of the colon, rectum, bladder, and kidney: a population-based study. Lancet 1999, 353:703-707.

14. Nagano J, Kono S, Preston DL, Moriwaki H, Sharp GB, Koyama K, Mabuchi K: Bladder-cancer incidence in relation to vegetable and fruit consumption: a prospective study of atomic-bomb survivors. Int J Cancer 2000, 86:132-138.

15. Wakai K, Takashi M, Okamura K, Yuba H, Suzuki K, Murase T, Obata K, Itoh H, Kato $T$, Kobayashi $M$, et al: Foods and nutrients in relation to bladder cancer risk: a case-control study in Aichi Prefecture, Central Japan. Nutr Cancer 2000, 38:13-22.

16. Balbi JC, Larrinaga MT, De Stefani $E$, Mendilaharsu M, Ronco AL, Boffetta $P$, Brennan P: Foods and risk of bladder cancer: a case-control study in Uruguay. Eur J Cancer Prev 2001, 10:453-458

17. Sakauchi F, Mori M, Washio M, Watanabe Y, Ozasa K, Hayashi K, Miki T, Nakao M, Mikami K, Ito Y, et al: Dietary habits and risk of urothelial cancer incidence in the JACC Study. J Epidemiol 2005, 15(Suppl 2):S190-195.

18. Baena AV, Allam MF, Del Castillo AS, Diaz-Molina C, Requena Tapia MJ, Abdel-Rahman AG, Navajas RF: Urinary bladder cancer risk factors in men a Spanish case-control study. Eur J Cancer Prev 2006, 15:498-503.

19. Holick CN, Giovannucci EL, Stampfer MJ, Michaud DS: A prospective study of fish, marine fatty acids, and bladder cancer risk among men and women (United States). Cancer Causes Control 2006, 17:1163-1173.

20. Garcia-Closas R, Garcia-Closas M, Kogevinas M, Malats N, Silverman D, Serra C, Tardon A, Carrato A, Castano-Vinyals G, Dosemeci M, et al: Food, nutrient and heterocyclic amine intake and the risk of bladder cancer. Eur J Cancer 2007, 43:1731-1740.

21. Hu J, La Vecchia C, DesMeules M, Negri E, Mery L: Meat and fish consumption and cancer in Canada. Nutr Cancer 2008, 60:313-324

22. Brinkman MT, Buntinx F, Kellen E, Van Dongen MC, Dagnelie PC, Muls E, Zeegers MP: Consumption of animal products, olive oil and dietary fat and results from the Belgian case-control study on bladder cancer risk. Eur J Cancer 47:436-442.

23. DerSimonian R, Laird N: Meta-analysis in clinical trials. Control Clin Trials 1986, 7:177-188.

24. Mantel N, Haenszel W: Statistical aspects of the analysis of data from retrospective studies of disease. J Natl Cancer Inst 1959, 22:719-748.

25. Higgins JP, Thompson SG, Deeks JJ, Altman DG: Measuring inconsistency in meta-analyses. BMJ 2003, 327:557-560.

26. Begg CB, Mazumdar M: Operating characteristics of a rank correlation test for publication bias. Biometrics 1994, 50:1088-1101.

27. Hardman WE: (n-3) fatty acids and cancer therapy. J Nutr 2004, 134:3427S-3430S.

28. Begin ME, Ells G, Das UN, Horrobin DF: Differential killing of human carcinoma cells supplemented with $n-3$ and n- 6 polyunsaturated fatty acids. J Natl Cancer Inst 1986, 77:1053-1062.

29. Reddy BS, Sugie S: Effect of different levels of omega-3 and omega- 6 fatty acids on azoxymethane-induced colon carcinogenesis in F344 rats. Cancer Res 1988, 48:6642-6647.

30. Rose DP, Connolly JM: Effects of dietary omega-3 fatty acids on human breast cancer growth and metastases in nude mice. J Natl Cancer Inst 1993, 85:1743-1747.

31. Kimura Y: Carp oil or oleic acid, but not linoleic acid or linolenic acid, inhibits tumor growth and metastasis in Lewis lung carcinoma-bearing mice. J Nutr 2002, 132:2069-2075.

32. Connolly JM, Coleman M, Rose DP: Effects of dietary fatty acids on DU145 human prostate cancer cell growth in athymic nude mice. Nutr Cancer 1997, 29:114-119.

33. Connolly JM, Gilhooly EM, Rose DP: Effects of reduced dietary linoleic acid intake, alone or combined with an algal source of docosahexaenoic acid, on MDA-MB-231 breast cancer cell growth and apoptosis in nude mice. Nutr Cancer 1999, 35:44-49.

doi:10.1186/1477-7819-9-107

Cite this article as: Li et al:: The association of fish consumption with bladder cancer risk: A meta-analysis. World Journal of Surgical Oncology 2011 9:107.

\section{Submit your next manuscript to BioMed Central and take full advantage of:}

- Convenient online submission

- Thorough peer review

- No space constraints or color figure charges

- Immediate publication on acceptance

- Inclusion in PubMed, CAS, Scopus and Google Scholar

- Research which is freely available for redistribution
C Biomed Central 